\title{
Drivers of the green supply chain initiatives: Evidence from Indonesian automotive industry
}

\author{
Danial Thaib ${ }^{\mathbf{a}^{*}}$
}

${ }^{a}$ Institute Bisnis dan Informatika Kosgoro, Indonesia

\begin{tabular}{l}
\hline C H R O N I C L E \\
\hline Article history: \\
Received July 12, 2019 \\
Received in revised format July \\
24,2019 \\
Accepted August 22019 \\
Available online \\
August 32019 \\
\hline Keywords: \\
Regulatory measure \\
Customer pressure \\
Indonesia \\
Automotive industry \\
Green initiatives
\end{tabular}

\section{Introduction}

Since the rise of the global warming and other environmental issues the end-user and environmental groups tend to be more curious and worried regarding how the organizations are working for the environmental sustainability. It is the phenomenon of every organization that the top management has acknowledged the large scale and ever-increasing environmental risks which also present in the supply chain processes. Organizations, NGOs, government agencies and stakeholders seem to be more concerned regarding the environment with the increasing impact of the organizations on the environment (Boyer et al., 2009; Sarkis et al., 2011; Abdeldayem \& Dulaimi 2019), thus, making the green initiatives as most suitable and preferred approach to tackle the environmental issues globally. It was argued that the majority of the green solutions are associated with conventional, command and control system. In these systems, organizations try to decrease their worst impacts on the environment.

* Corresponding author

E-mail address: danithaib@gmail.com (D. Thaib)

C 2020 by the authors; licensee Growing Science. doi: $10.5267 /$ j.uscm.2019.8.002 
Even though organizations have acknowledged the importance of the green initiatives and implemented these ones but still there are some reasons which weaken these initiatives. Sarkis (2006) argued that command and control approach is not suitable and cannot eradicate the pollutants. It can only make transformation of one pollutant from one nature to other. Furthermore, when organizations only do emphasize on the problems related to the system within them, it leads them towards the negative spillover effects which happen due to the unacceptable performance its supply chain partners regarding the environment. It can be elaborated by an example of small supplier who do follow the poor standards and have poor environmental performance and potentially influence the corporate image of a big organization in the same supply chain (Christmann \& Taylor, 2001; Cousins et al., 2004; Abdulrasheed, 2017). Thus, it can be stated that organizations must focus on internal and external channels for positive improvement on the impact they are exerting on the environment. It is important to talk about the stake holders as they are the key factor to which organizations are responsible. Sarkis (2006) argued that it is quite rare that the stakeholders do differentiate the performance of a company and its suppliers regarding the poor environmental practices they follow. Number of firms have adopted the external approaches (external green supply chain initiatives) to lessen their resources waste and pollution which resides in their supply chain. However, in the opinion of previous researchers it is actually the comprehensive obligation which applies to a wide range of organizations in forwards and backward integration (Jayaraman, 2006; Vachon \& Klassen, 2006; Adjei, 2018). World has become a global village which has also provided the firms with an opportunity in the developing economies to practice the better rules and regulations regarding the environment. Having the importance of the topic, the present study focuses on the environmental concerns in the Indonesia. For the purpose of the study, Indonesian automotive industry is selected as it is the market leader in the ASAEN region regarding the car sales. This sector has major contribution towards the GDP in Indonesia over the years. The contribution of automotive sector in Indonesian GDP was 5.6\%, 5\%, 4.9\% and 5\% in 2013, 2014, 2015 and 2016 respectively. Table 1 shows the sales amount of auto makers:

Table 1

The amount of investment in auto-industry

\begin{tabular}{ccccc}
\hline Country & 2014 & 2015 & 2016 & 2017 \\
\hline Thailand & 881,832 & 799,632 & 768,788 & 871,650 \\
Indonesia & $1,208,019$ & $1,013,291$ & $1,062,716$ & $1,079,534$ \\
Malaysia & 666,465 & 666,674 & 580,124 & 576,635 \\
Philippines & 234,747 & 288,609 & 359,572 & 425,673 \\
Vietnam & 133,588 & 209,267 & 270,820 & 250,619 \\
Singapore & 47,443 & 78,609 & 110,455 & 116,148 \\
Brunei & 18,114 & 14,406 & 13,248 & 11,209 \\
\hline ASEAN & $3,190,208$ & $3,070,488$ & $3,164,742$ & $3,331,468$ \\
\hline
\end{tabular}

Source: Indonesia-Investments (2018)

Organizations who win award regarding the environmental performance are considered as benchmark for improved environmental performance. It was contended that different approaches can be followed to cope with the environmental issues such as going for joint ventures, partnerships with the organizations in the developed worlds in order to adopt the green supply chain initiatives (Zhu \& Liu, 2010; AlAli, 2016). Thus, this study is focused to explore the relationship between certain factors that can lead towards the green supply chain initiatives. Competitor pressures, customer pressure, regulatory measures and socio-cultural responsibility have been considered as factors that drive the green supply chain initiatives. Previously there are only few studies available which specifically explore the different factors in a bundle leading towards the green supply chain initiatives. The present study contributes to the literature by providing the relationship between drivers and green supply chain initiatives. This section of the study explains the purpose and rationale to conduct the study. The next sections 
summarize the available empirical evidence on the under study variables, methods, results and finally we provide the conclusion with the future directions for more research.

\section{Literature Review}

\subsection{Green supply chain initiatives}

According to Zsidisin and Siferd (2001), an organization might originate a set of deeds to decrease the negative environment special effects related to the perfect life expectancy of its goods and services, beginning from good's designs to attainment of raw materials to utilization and product disposal. Moreover, the concepts of green supply chain management is not widespread in spite of its environmental benefits. Even though the conception of a green supply chain has progressed further than a firm specific or end results of green solution (Zhu et al., 2007; Albasu \& Nyameh 2017). According to Rao (2006), most of the organizations provoke a potential lack of green resources, proficiency and competences (Matos \& Hall, 2007). Still, the researchers are not in one line regarding the relationship of green supply chain initiatives (Zhu et al., 2005; Aldulaimi, 2018). The literature on green supply chain management has concentrated diversity of literature extending from activities of organization to inflexible models that assess the green supply chain practices and technology (Hall, 2000; Aldulaimi \& Abdeldayem 2018). Green supply chain initiatives seem very expensive and recommend indeterminate returns (Linton et al., 2007; Ale, 2018).

\subsection{Regulatory Measures}

To inspire and convert an environmentally responsible organization, regulatory measures take the form of laws, principles, processes and incentives set by regulatory institutions. Literature on regulatory measures described that the regulatory measures provided supply chain benefits to the organizations by regulatory requirements imposed by governments and regulatory bodies (Bansal \& Roth, 2000; Almeqdadi, 2018). According to Clemens and Douglas (2006), regulation in developing economies improves their environmental activities and in developed economies basic foundation can increase in institutional pressures for organization. So, the pressure in economies forced the organizations to introduce the environmental functions that have exceeded expectancy. Another study concluded that how China as developing economy enacted strict regulations that beaten the own country and global requirements. This study also elaborated how china determined manufacturers to implement green supply chain activities that influence organization performance (Zhu \& Sarkis, 2004; Aregbeyen \& Fasanyan 2017). In the results, regulatory measures items encompassed incentives imposed on organization by regulatory institution and environmental regulations. Further, government agencies form powerful institutions forcefully stimulate the organizations to follow the environmental management practices. They imposed fines and trade barriers on those organizations that would not follow the green supply chain practices. By using regulatory measures and incentives an organizations can adopt the green purchasing practices coercive measures increases the formal and informal pressures exerted on organization for using green management practices (Rivera et al., 2006; Satya \& Kuraesin 2016). Similarly Kilbourne (2002), described how purchasing raw materials, design the products and process according to environment and converse logistics practices were used by organizations. So, it indicated that coercive pressure was important to drive the organization to regulate the environmental management practices. One more study concluded how environmental awareness was improved by coercive pressures through laws and regulations and consequently urge the environmental management practices (Sarkis et al., 2011; Sethi \& Ghatak 2018).

\subsection{Socio Culture Responsibility}

Jones (1999) defined the socio culture responsibility as a volunteer obligation towards society to attain the synchronization with norms, codes of ethics, and social prospects that are directive the acceptable organizational behaviors. According to research on organization operations, the multinational 
organizations have a sense of responsibilities in the direction of the societal benefits (Murphy \& Poist, 2003; Setiyawati, Iskandar \& Basar 2018). Hence, these companies go for the application of the green practices to build a socially desired repute which is in line with the responsibilities and norms of the societies in which they do operate. Furthermore, previously studies have also reported that the companies are asked to meet their obligation towards the society by the development of eco-friendly products. Empirical and theoretical evidence available in the domain of business ethics contends that socio-cultural responsibility denotes to the conviction that positive citizenship asks for the positive acts towards the society and not damage the society by the firms (Florida \& Davison, 2001; Shieh, 2016). Thus, it was stated that the socio-cultural responsibility concept is inclusive of the ethical duty of a company towards the environment. Arguing from the perspective of institutional theory, culturalcognitive isomorphism is because of the organizational realistic aspiration to go for the behaviors which are technically sound.

Green supply chain initiatives are found to be influenced by the socio-cultural responsibility. Preuss (2001), considered the green purchasing and reverse logistics as potential green supply chain initiative. There are different cases to be mentioned regarding this phenomenon. Multinational organizations in Malaysia have adopted the green supply chain initiatives which further boost their progress towards the accomplishment of their ultimate objective (Socio-cultural responsibility). At this point, it is worthy to mention the case of General Mills which utilizes the palm oil as the major constituent for its process of manufacturing (Parmigiani et al., 2011; Sianturi \& Tampubolon 2017). A significant amount of the palm oil is distributed to world by Indonesia and Malaysia. However, the deforestation is the key concern there as well. The stakeholders do influence the adoption of the green practices. Interestingly, Schwartz (2010), points out that major stakeholder in the developed economies such as USA are pushing the General Mills to look out for more environment friendly sources for the major components of their manufacturing processes. Continuing on the sustainable manufacturing it is worthy to mention that shift from conventional to environment friendly constituents do potentially reduce the influence on the environment and looking for the productive ways to test the sources of getting raw material to be the most important task for the manufacturers. Because of the global competitiveness, the companies in the developing economies have to learn the practices from the other companies operating in the developed economies. The increasing pressure of social and cultural obligation is the key motivating factor for the organizations to go for the production with minimal resource and energy usage. It has also resulted in increased know how among the supply chain members to adopt the sources for products return, their recycling and their remanufacturing as well (Tyagi \& Siddiqui 2017).

\subsection{Customer Pressure}

The increasing environmental concerns have made the environmental discussion popular among general public as well. In this regard it was argued that due to the environmental problems now the end-user has also started to raise questions regarding the impact of the products which do they buy and anticipate the companies to adopt the minimum green criterion in their products and processes (Tate et al., 2010; Wong, 2016). Most of studies point out that pressure from consumers force organization and members of downstream supply chain adopt the initiatives of green supply chain (Wolf, 2011; Yamaguchi, 2018). According to institutional theory, normative pressure is extended by exterior stakeholders who have high level of attention in the organization such as customers (Vachon et al., 2009). Normative pressure cores the organization be perceived as more truthful and follow all the legal obligations (Sarkis et al., 2011; Wonyra, 2018a).

One study accomplished in Malaysian manufacturers described that the customers' enforcement to adopt the green supply chain initiatives developed the basic normative pressure. Furthermore, by exporting goods to the large developed countries enforce the Malaysian manufactures to adopt the environment friendly suppliers. Moreover, these developed countries pressurize the developing economy to consider the environment friendly initiatives while designing the product, reduce the 
negative results of products on economy throughout the life, and stimulate reutilizing and reprocess of the product. Thus, it can be stated that Indonesia as a developing economy has to face the normative pressures from developed economies to follow the green supply chain initiatives (Hitchcock, 2012; Wonyra, 2018b). Likewise, other developing economy Indonesia confronts assorted variety of waste disposal challenges. There is a lack of legislation for waste disposal. So, for reducing that issues in organization the organization must introduce the environment friendly concept in economy and in organization upper to bottom supply chain practices.

\subsection{Competitor Pressure}

Today organizations face many challenges from competitors to adopt the green supply chain initiatives. Most organizations face deep examination from external protesters and competitors also (Zhu \& Sarkis, 2007). For gaining the competitive edge in organization, the competitors stimulate the organization to follow the legislation of green supply chain management. The organization can get the edge on to others organizations by designing the product that can be used and recycled also. Similarly, organizations gain a sustainable competitive advantage by using the green initiatives action (Hart, 1995). Thus, for attaining the competitive edge in organization, firms must give orientation to employees for pollution prevention, product administration, and strategies for sustainable development. According to Zhu et al. (2008), a manufacturer gets the additional source of money by taking back the products and resells the products after renovating the products, and using its market acuteness, status, higher access to genuine parts, and potential to efficiently renovate and used products at home.

\subsection{Theoretical Model and Hypothesis Development}

$\mathrm{H}_{1}$. There is a positive relationship between regulatory measures and green supply chain initiatives.

$\mathrm{H}_{2}$. There is a positive relationship between customer pressure and green supply chain initiatives.

$\mathrm{H}_{3}$. Social culture responsibility has significant and positive relationship with green supply chain initiatives.

$\mathrm{H}_{4}$. There is a positive relationship between competitor pressure and green supply chain initiatives.

Fig. 1 shows the theoretical framework of this study:

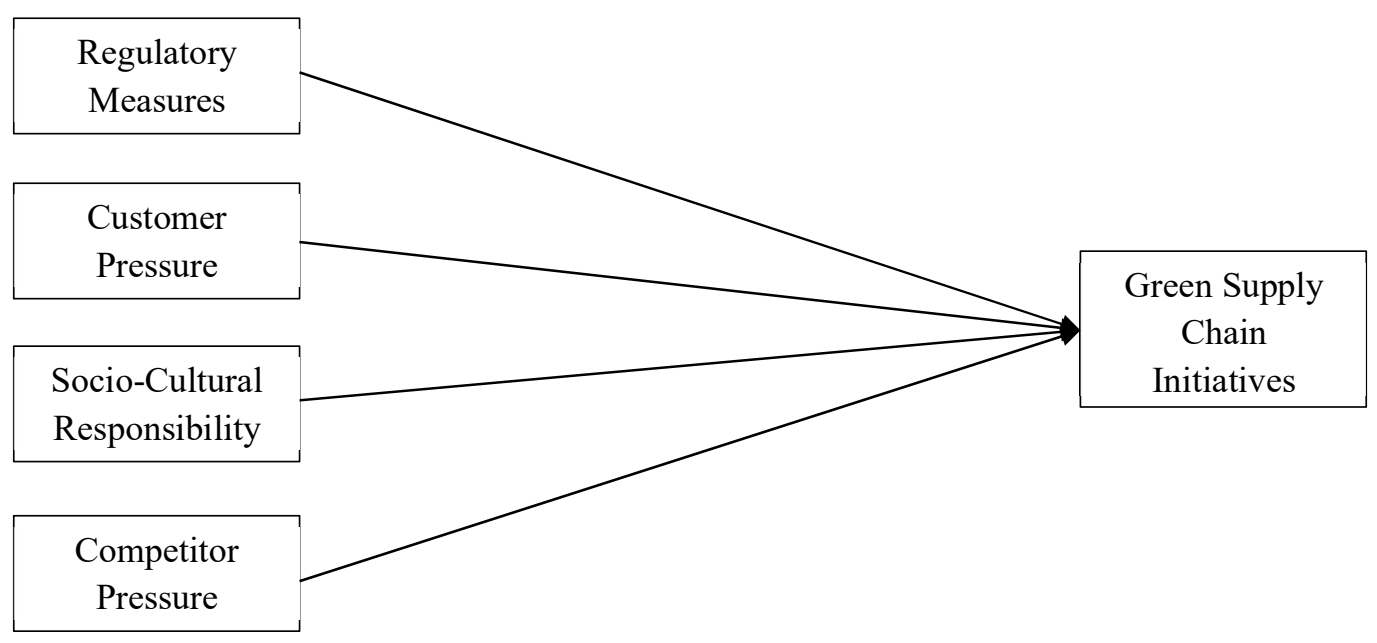

Fig. 1. The structure of the proposed model 


\section{Methodology}

The present study attempts to elaborate the green supply chain management drivers and their effects on the green supply chain initiatives, which falls under different domains such as legal regulations, endusers, culture and market as well. The study is quantitative and descriptive in nature. The study was conducted in Indonesia Automotive industry. It was selected because Indonesia was ranked as $1^{\text {st }}$ automotive seller of Southeast Asia in 2016 with a contribution of 5\% to GDP (Indonesia-Investments, 2018).

First of all, the sample size was selected for the study. For the purpose of selecting an appropriate sample size list of companies was obtained which falls under the broad domain of automotive industry. There are 20 sole agents, 9 distributors and 11 manufacturers registered with the Association of Indonesia Automotive Industries (GAIKINDO, 2019). There are different techniques to select sample size. Krejcie and Morgan (1970), provided a table for sample size selection. Oke et al. (2012), argued that the sample size should be from 200 to 400. Whereas Barlett et al. (2001), argued that sample size should represent at least $20 \%$ of the population. Present study has used the Krejcie and Morgan (1970) table for the sample size selection. According to which the sample size is 300 .

Sampling technique was selected after the sample size determination. Simple random sampling was used to collect data from the respondents. It is selected because it reduces the bias which happens in non-probability sampling. The questionnaires were designed to collect data which consists of two parts. The first parts addressed the personal profile of the respondents whereas the second part addressed the variables under study namely; regulatory measures, customer pressure, socio-cultural responsibility, competitor pressure and green supply chain practices.

For all the variables, measures were adopted from previous studies. Regulatory measures and competitors pressure were measured by adopting 6 items scale each (Carter \& Carter, 1998; Darnall, 2006; Zhu et al., 2007). Customer pressure was measured by using the scale of normative pressure which consisted of 5 items (Darnall, 2006). Socio-cultural responsibility was measured by adopting 6 items (Hsu et al., 2013). Green initiatives were measured by using 19 items (Zhu et al., 2007). After the data collection there were 210 useable responses which were considered for data analysis. The next section of the present study consists of the results and their interpretation.

\section{Findings}

Table 2 presents the confirmatory factor analysis of the survey. Before proceeding for the hypothesis tests, there is a need to confirm the validity and reliability of the scale. Reliability measures the internal consistency of the items within the questionnaire. Cronbach's Alpha is used for the reliability of the scale and it should be more than 0.7. As per table the values for the Alpha of variables namely; competitors' pressure, customer pressure, green supply chain initiatives, regulatory measures and socio-cultural responsibility are $0.856,0.703,0.907,0.860$ and 0.863 , respectively. Table 2 shows the values for the factor loadings, which are regarded as one of the criteria for the convergent validity. For the factor loadings the value should be more than 0.7 . However, the value for the factor loading is also acceptable if it is 0.5 . As per the table the values of the factor loadings for all items are more than 0.5. Thus, it satisfies the first criterion. CR stands for composite reliability which is the second criterion for the convergent validity. Its value must be greater than 0.8 . As per the table, all the values are greater than 0.8 , thus satisfying the second criterion. AVE stands for average variance extract the third criterion and its value must be more than 0.5. As per the table all the values for the AVE are greater than 0.5 thus satisfying the third criterion. Conclusively, all the criteria for the convergent validity are fulfilled. 
Table 2

Confirmatory factor analysis

\begin{tabular}{|c|c|c|c|c|c|}
\hline Constructs & Items & Loadings & Alpha & $\mathbf{C R}$ & AVE \\
\hline \multirow[t]{6}{*}{ Competitors Pressure } & $\mathrm{CP} 1$ & 0.770 & 0.856 & 0.894 & 0.587 \\
\hline & $\mathrm{CP} 2$ & 0.772 & & & \\
\hline & CP3 & 0.785 & & & \\
\hline & $\mathrm{CP} 4$ & 0.604 & & & \\
\hline & $\mathrm{CP5}$ & 0.841 & & & \\
\hline & CP6 & 0.802 & & & \\
\hline \multirow[t]{4}{*}{ Customer Pressure } & Cus. P1 & 0.812 & 0.703 & 0.812 & 0.522 \\
\hline & Cus. P2 & 0.731 & & & \\
\hline & Cus. P3 & 0.750 & & & \\
\hline & Cus. P4 & 0.577 & & & \\
\hline \multirow[t]{11}{*}{ Green Supply Chain Initiatives } & GSCI1 & 0.722 & 0.907 & 0.922 & 0.519 \\
\hline & GSCI10 & 0.734 & & & \\
\hline & GSCI11 & 0.616 & & & \\
\hline & GSCI2 & 0.727 & & & \\
\hline & GSCI3 & 0.777 & & & \\
\hline & GSCI4 & 0.774 & & & \\
\hline & GSCI5 & 0.736 & & & \\
\hline & GSCI6 & 0.723 & & & \\
\hline & GSCI7 & 0.711 & & & \\
\hline & GSCI8 & 0.690 & & & \\
\hline & GSCI9 & 0.700 & & & \\
\hline \multirow[t]{6}{*}{ Regulatory Measures } & RM1 & 0.806 & 0.86 & 0.895 & 0.589 \\
\hline & RM2 & 0.828 & & & \\
\hline & RM3 & 0.726 & & & \\
\hline & RM4 & 0.757 & & & \\
\hline & RM5 & 0.802 & & & \\
\hline & RM6 & 0.675 & & & \\
\hline \multirow[t]{6}{*}{ Socio-cultural Responsibility } & SR1 & 0.75 & 0.863 & 0.898 & 0.594 \\
\hline & SR2 & 0.798 & & & \\
\hline & SR3 & 0.788 & & & \\
\hline & SR4 & 0.777 & & & \\
\hline & SR5 & 0.743 & & & \\
\hline & SR6 & 0.768 & & & \\
\hline
\end{tabular}

\section{Discriminant validity}

Table 3

The results of discriminant validity

\begin{tabular}{cccccc}
\hline & CP & Cus. P & GSCI & RM & SR \\
\hline CP & & & & & \\
Cus. P & 0.232 & & & \\
GSCI & 0.691 & 0.277 & & \\
RM & 0.543 & 0.174 & 0.711 & & \\
SR & 0.680 & 0.245 & 0.884 & 0.695 \\
\hline
\end{tabular}

Sometimes a measure of a certain variable may represent the other variable. So, discriminant validity is calculated in order to make sure the extent to which a measure do not represent the other variable. There are two techniques for the assessment of discriminant validity known as "Fornell-Larcker Criterion," and "Hetrotrain-Monotrait Correlation Ratio". Thisstudy has used the HTMT for the discriminant validity. According to which the correlation between variables should be less than 0.85 and from some other criterion should be less than 0.90 . As per the table all the values are less than 0.85 which establish the discriminant validity and allows to procced for the hypothesis test. Fig. 2 shows the confirmatory factor analysis: 


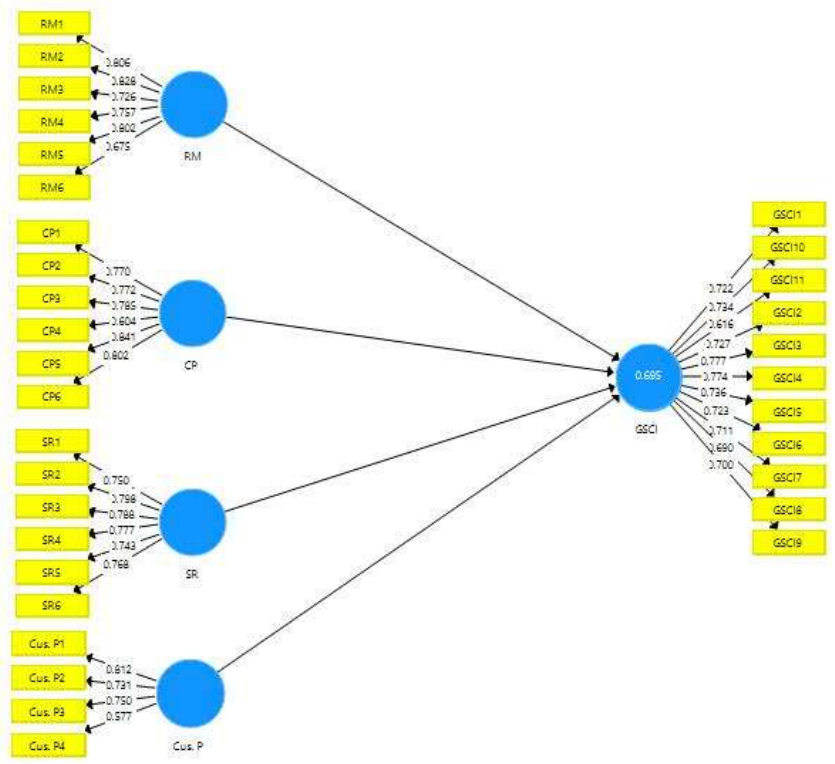

Fig. 2. Measurement Model Assessment

Structural Equation Modeling

Table 4

The summary of the structural modelling results

\begin{tabular}{cccccccc}
\hline Relationship Hypothesis & Beta & SD & $t$ & $\mathrm{p}$ & Decision & $f 2$ & VIF \\
$\mathrm{CP} \rightarrow$ GSCI & 0.182 & 0.026 & 6.974 & $\mathrm{p}<0.05$ & Supported & 0.068 & 1.582 \\
$\mathrm{Cus} . \mathrm{P} \rightarrow$ GSCI & 0.065 & 0.021 & 3.092 & $\mathrm{p}<0.05$ & Supported & 0.013 & 1.049 \\
$\mathrm{RM} \rightarrow$ GSCI & 0.223 & 0.027 & 8.193 & $\mathrm{p}<0.05$ & Supported & 0.098 & 1.652 \\
$\mathrm{SR} \rightarrow$ GSCI & 0.536 & 0.030 & 18.027 & $\mathrm{p}<0.05$ & Supported & 0.477 & 1.977 \\
\hline
\end{tabular}

Table 4 shows the results for the structural equation modeling. As per the table competitor pressure and green supply chain initiative is positively linked with the green supply chain initiatives. The value of relationship is 0.182 which asserts that 1 unit increase in competitor pressure will bring about 18 units change in green supply chain initiative. Generally speaking when the suppliers of an organization are following the environmentally sustainable practices it will ultimately put pressure on the organization to also adopt the similar practices. Results are significant thus supported the hypothesis. Furthermore, $f 2$ is showing the effect size for the competitor pressure is small. VIF value for the competitor pressure and green supply chain initiative is 1.582 which shows that there is no issue of multi-collinearity. Furthermore, customer pressure is also found to be considerable related with the green supply chain initiatives. Beta value of the relationship is 0.065 . The value is low but the relationship is significant as $t$ value is also more than the acceptable range, VIF value is also 1.049 affirming that there is no multicollinearity issue. However, the effect size for this relationship was also low as it is valued at 0.013 only. From the results it is interpreted that due to the customer awareness they are asking the companies to be environmentally responsible. With the increasing concerns about the environment organizations are forced to employ the green initiatives in their business operations.

Moreover, as per the study results statistically there is positive relationship between regulatory measures and green supply chain initiatives. The effect size for the regulatory measures is 0.098 which is considerable effect. Similarly, the $t$ value is 8.193 and 1.652 value of VIF indicates that there is no issue of multi-collinearity. The relationship is valued at $22 \%$ which means that with the stronger and strict regulations there will be more green initiatives. Therefore, it is stated that companies are forced to go for green initiatives in their operations due to the strict rules and regulations. Environmental 
certifications such as ISO 140001 and 14000 are specifically related to the environment management. The firms have to follow all the rules and regulations, employ them and maintain them to avail and retain the certification. Finally, results also reported that socio-cultural responsibilities also influence the green supply chain initiative. The effect size for the socio-cultural responsibilities is large and valued at 0.477 . It is the strongest of all the variables in the research framework. It emerged to be a strong predictor as the value for the Beta is 0.536 approaching approximately $54 \%$. There is no multicollinearity issue as the value for the VIF is 1.977 . Hence, it is stated that when there is strong culture of social responsibility the organizations will tend to implement the green initiatives in their operations. Fig. 3 shows the results of SEM:

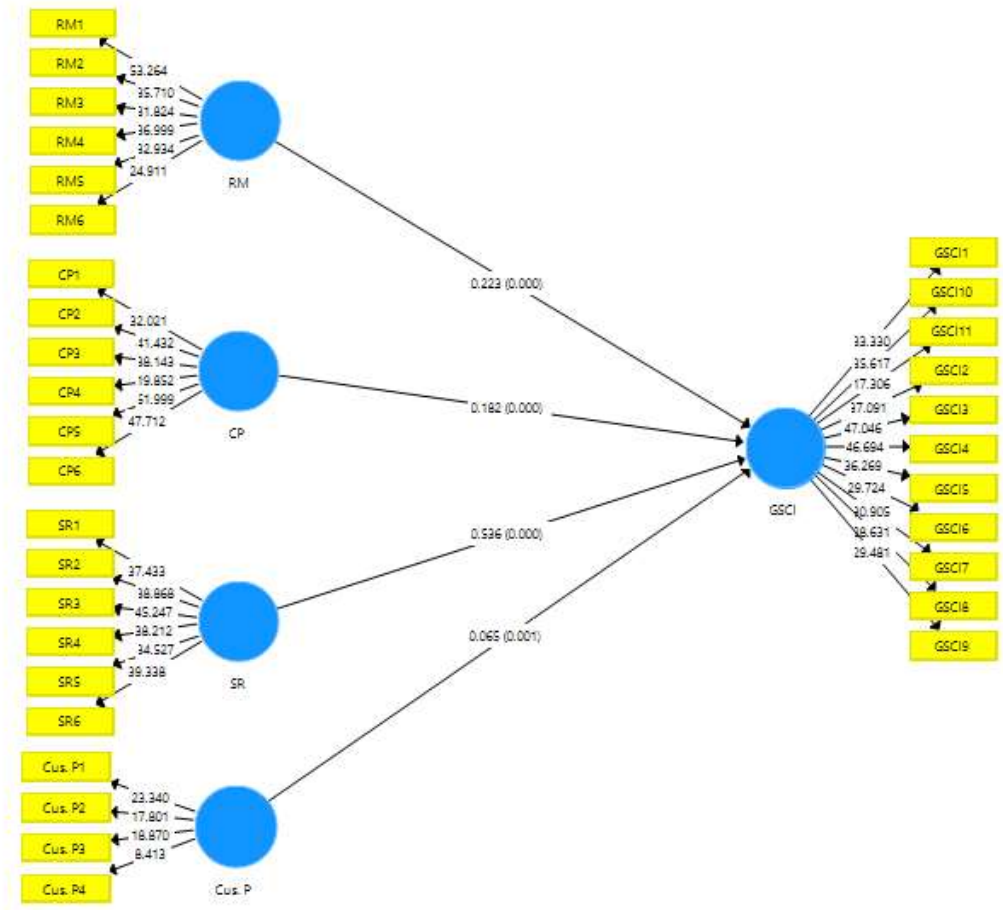

Fig. 3. Structural Equation Modeling

\section{Discussion}

The current study was to explore the relationship between green supply chain initiatives and competitor pressures, customer pressure, regulatory measures and socio-cultural responsibility. These factors have been considered the crucial factors that drive the green supply chain initiatives. The study shows that the regulatory measures and green supply chain initiatives had significant and positive relationship. Previous studies also elaborated that there was a positive relationship between them (Rivera et al., 2006; Sarkis et al., 2011). The socio-culture responsibility and customer pressure have also maintained positive and significant relationship between green supply chain initiatives. The relationship between these variables were also described by previous researches (Parmigiani et al., 2011; Sarkis et al., 2011; Schwartz, 2010; Wolf, 2011), in this way the $2^{\text {nd }}$ and $3^{\text {rd }}$ hypotheses were also accepted. The $4^{\text {th }}$ hypothesis was also accepted and it shows that there was a positive relationship between competitor's pressure and green supply chain initiatives and previous studies also provided that there was a positive relationship between them(Zhu \& Sarkis, 2007; Zhuet al., 2008; Zhu et al., 2008).

The data were collected from automotive industries by considering only large-scale organizations. In future, other researchers may consider the small and medium size organization in their sample and also can collect the data from service industry to know the trend of the mentioned drivers on green supply chain initiatives in service industry. The study is cross sectional in nature, further researchers can consider the longitudinal study for gaining the in-depth analysis on these drivers. 


\section{References}

Abdeldayem, M. M., \& Dulaimi, S. H. A. (2019). Privatisation as a worldwide tool of economic reform: A literature Review. International Journal of Social and Administrative Sciences, 4(2), 66-84.

Abdulrasheed, B. (2017). Causality between government expenditure and government revenue in Nigeria. Asian Journal of Economics and Empirical Research, 4(2), 91-98.

Adjei, S. K. (2018). Inflation determinants-milton friedman's theory and the evidence from Ghana, 1965-2012 (Using ARDL Framework). International Journal of Applied Economics, Finance and Accounting, 3(1), 21-36.

AlAli, M. S. (2016). Forecasting-based carry trade using pegged currency: A case of Omani rial. The Economics and Finance Letters, 3(2), 21-29.

Albasu, J., \& Nyameh, J. (2017). Relevance of stakeholders theory, organizational identity theory and social exchange theory to corporate social responsibility and employees performance in the commercial banks in Nigeria. International Journal of Business, Economics and Management, 4(5), 95-105.

Aldulaimi, S. H. (2018). The influence of national culture on commitment that produce behavioral support for change initiatives. International Journal of Applied Economics, Finance and Accounting, 3(2), 64-73.

Aldulaimi, S. H., \& Abdeldayem, M. M. (2018). The economic value of time in Arab culture: New evidence using Zimbardo Time Perspective Inventory (ZTPI). American Journal of Social Sciences and Humanities, 3(1), 63-72.

Ale, A. S. (2018). Assessment of dual carriageway for sustainable socio-economic development in Ado Ekiti, Nigeria. International Journal of Sustainable Development \& World Policy, 7(1), 27-36.

Almeqdadi, F. (2018). The effects of using an Interactive Software (GSP) on UAE Students' Attitudes towards Geometry. American Journal of Social Sciences and Humanities, 3(1), 22-28.

Aregbeyen, O., \& Fasanyan, I. O. (2017). Oil price volatility and fiscal behaviour of government in Nigeria. Asian Journal of Economic Modeling, 5(2), 118-134.

Bansal, P., \& Roth, K. (2000). Why companies go green: A model of ecological responsiveness. Academy of Management Journal, 43(4), 717-736.

Barlett, J. E., Kotrlik, J., \& Higgins, C. C. (2001). Organizational research: Determining appropriate sample size in survey research. . Information Technology, Learning, and Performance Journal, $19(1), 43$.

Boyer, K. K., Prud'homme, A. M., \& Chung, W. (2009). The last mile challenge: evaluating the effects of customer density and delivery window patterns. Journal of Business Logistics, 30(1), 185-201.

Carter, C. R., \& Carter, J. R. (1998). Interorganizational determinants of environmental purchasing: initial evidence from the consumer products industries. Decision Sciences, 29(3), 659-684.

Christmann, P., \& Taylor, G. (2001). Globalization and the environment: Determinants of firm selfregulation in China. Journal of International Business Studies, 32(3), 439-458.

Clemens, B., \& Douglas, T. J. (2006). Does coercion drive firms to adopt 'voluntary'green initiatives? Relationships among coercion, superior firm resources, and voluntary green initiatives. Journal of Business Research, 59(4), 483-491.

Cousins, P. D., Lamming, R. C., \& Bowen, F. (2004). The role of risk in environment-related supplier initiatives. International Journal of Operations \& Production Management, 24(6), 554-565.

Darnall, N. (2006). Why firms mandate ISO 14001 certification. Business \& Society, 45(3), 354-381.

Florida, R., \& Davison, D. (2001). Gaining from green management: environmental management systems inside and outside the factory. California Management Review, 43(3), 64-84.

GAIKINDO. (2019). Gabungan Industri Kendaraan Bermotor Indonesia. Retrieved 20 June, 2019, from https://www.gaikindo.or.id/en/member/

Hall, J. (2000). Environmental supply chain dynamics. Journal of Cleaner Production, 8(6), 455-471.

Hart, S. L. (1995). A natural-resource-based view of the firm. Academy of Management Review, 20(4), 986-1014. 
Hitchcock, T. (2012). Low carbon and green supply chains: the legal drivers and commercial pressures. Supply Chain Management: An International Journal, 17(1), 98-101.

Hsu, C.-C., Choon Tan, K., Hanim Mohamad Zailani, S., \& Jayaraman, V. (2013). Supply chain drivers that foster the development of green initiatives in an emerging economy. International Journal of Operations \& Production Management, 33(6), 656-688.

Indonesia-Investments. (2018). Automotive Manufacturing Industry Indonesia. Retrieved 20 June, 2019, from https://www.indonesia-investments.com/business/industries-sectors/automotiveindustry/item6047

Jayaraman, V. (2006). Production planning for closed-loop supply chains with product recovery and reuse: an analytical approach. International Journal of Production Research, 44(5), 981-998.

Jones, M. T. (1999). The institutional determinants of social responsibility. Journal of Business Ethics, 20(2), 163-179.

Kilbourne, J. (2002). Killing Us Softly 3 (STREAMING VIDEO): Advertising's Image of Women.

Krejcie, R. V., \& Morgan, D. W. (1970). Determining sample size for research activities. Educational and Psychological Measurement, 30(3), 607-610.

Linton, J. D., Klassen, R., \& Jayaraman, V. (2007). Sustainable supply chains: An introduction. Journal of Operations Management, 25(6), 1075-1082.

Matos, S., \& Hall, J. (2007). Integrating sustainable development in the supply chain: The case of life cycle assessment in oil and gas and agricultural biotechnology. Journal of Operations Management, 25(6), 1083-1102.

Murphy, P. R., \& Poist, R. F. (2003). Green perspectives and practices: a "comparative logistics" study. Supply Chain Management: An International Journal, 8(2), 122-131.

Oke, A. E., Ogunsami, D. R., \& Ogunlana, S. (2012). Establishing a common ground for the use of structural equation modelling for construction related research studies. Construction economics and building, 12(3), 89-94.

Parmigiani, A., Klassen, R. D., \& Russo, M. V. (2011). Efficiency meets accountability: Performance implications of supply chain configuration, control, and capabilities. Journal of Operations Management, 29(3), 212-223.

Preuss, L. (2001). In dirty chains? Purchasing and greener manufacturing. Journal of Business Ethics, 34(3-4), 345-359.

Rao, P. (2006). Greening of suppliers/in-bound logistics - in the south East Asian context Greening the supply chain (pp. 189-204): Springer.

Rivera, J., De Leon, P., \& Koerber, C. (2006). Is greener whiter yet? The sustainable slopes program after five years. Policy Studies Journal, 34(2), 195-221.

Sarkis, J. (2006). Greening the supply chain: Springer.

Sarkis, J., Zhu, Q., \& Lai, K.-h. (2011). An organizational theoretic review of green supply chain management literature. International Journal of Production Economics, 130(1), 1-15.

Schwartz, A. (2010). General Mills ditches dirty palm oil. Fast Company online. http://www. fastcompany. com/1690894/general-mills-ditches-dirty-palm-oil (accessed 16.12. 2010).

Satya, M. T., \& Kuraesin, A. (2016). Analysis place branding as a local culture Kampung Naga West Java Indonesia. International Journal of Management and Sustainability, 5(2), 11-16.

Sethi, D., \& Ghatak, S. (2018). Mitigating cyber sexual harassment: An Insight from India. Asian Themes in Social Sciences Research, 1(2), 34-43.

Setiyawati, H., Iskandar, D., \& Basar, Y. S. (2018). The quality of financial reporting through increasing the competence of internal accountants and accrual basis. International Journal of Economics, Business and Management Studies, 5(1), 31-40.

Shieh, C. H. (2016). The investment performance of socially responsible investment in Japan. The Economics and Finance Letters, 3(1), 1-7.

Sianturi, K., \& Tampubolon, M. (2017). The influence of communication, work Motivation and Career Development on Elementary School Teacher's Job Performance in Medan, Indonesia. International Journal of Business, Economics and Management, 4(6), 124-135. 
Tyagi, S., \& Siddiqui, S. (2017). Yield curve and momentum effects in monthly US equity returns: Some nonparametric evidence. Asian Journal of Economics and Empirical Research, 4(2), 61-67.

Tate, W. L., Ellram, L. M., \& Kirchoff, J. F. (2010). Corporate social responsibility reports: a thematic analysis related to supply chain management. Journal of Supply Chain Management, 46(1), 19-44.

Vachon, S., Halley, A., \& Beaulieu, M. (2009). Aligning competitive priorities in the supply chain: the role of interactions with suppliers. International Journal of Operations \& Production Management, 29(4), 322-340.

Vachon, S., \& Klassen, R. D. (2006). Extending green practices across the supply chain: the impact of upstream and downstream integration. International Journal of Operations \& Production Management, 26(7), 795-821.

Wolf, J. (2011). Sustainable supply chain management integration: a qualitative analysis of the German manufacturing industry. Journal of Business Ethics, 102(2), 221-235.

Wong, E. Y. (2016). Development of mobile voice picking and cargo tracing systems with internet of things in third-party logistics warehouse operations. International Journal of Management and Sustainability, 5(4), 23-29.

Wonyra, K. O. (2018a). Impact of telecommunications market liberalization on labor productivity in economic community of west African States. Journal of Social Economics Research, 5(2), 63-74.

Wonyra, K. O. (2018b). Industrialization and economic growth in sub-saharan Africa: The role of human capital in structural transformation. Journal of Empirical Studies, 5(1), 45-54.

Yamaguchi, M. (2018). Are foreign banks in China homogenous?: Classification of their business patterns. Journal of Accounting, Business and Finance Research, 3(1), 10-17.

Zhu, Q., \& Liu, Q. (2010). Eco-design planning in a Chinese telecommunication network company: benchmarking its parent company. Benchmarking: An International Journal, 17(3), 363-377.

Zhu, Q., \& Sarkis, J. (2004). Relationships between operational practices and performance among early adopters of green supply chain management practices in Chinese manufacturing enterprises. Journal of Operations Management, 22(3), 265-289.

Zhu, Q., \& Sarkis, J. (2007). The moderating effects of institutional pressures on emergent green supply chain practices and performance. International Journal of Production Research, 45(18-19), 43334355.

Zhu, Q., Sarkis, J., Cordeiro, J. J., \& Lai, K.-H. (2008). Firm-level correlates of emergent green supply chain management practices in the Chinese context. Omega, 36(4), 577-591.

Zhu, Q., Sarkis, J., \& Geng, Y. (2005). Green supply chain management in China: pressures, practices and performance. International Journal of Operations \& Production Management, 25(5), 449-468.

Zhu, Q., Sarkis, J., \& Lai, K.-h. (2007). Green supply chain management: pressures, practices and performance within the Chinese automobile industry. Journal of Cleaner Production, 15(11-12), 1041-1052.

Zhu, Q., Sarkis, J., \& Lai, K.-h. (2008). Green supply chain management implications for "closing the loop". Transportation Research Part E: Logistics and Transportation Review, 44(1), 1-18.

Zsidisin, G. A., \& Siferd, S. P. (2001). Environmental purchasing: a framework for theory development. European Journal of Purchasing \& Supply Management, 7(1), 61-73.

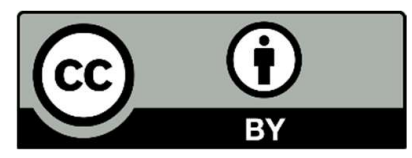

(C) 2020 by the authors; licensee Growing Science, Canada. This is an open access article distributed under the terms and conditions of the Creative Commons Attribution (CC-BY) license (http://creativecommons.org/licenses/by/4.0/). 